\section{Effects of Denture Cleansers on Heat-Polymerized Acrylic Resin: A Five-Year-Simulated Period of Use}

Carolina Noronha Ferraz Arruda, Danilo Balero Sorgini, Viviane de Cássia Oliveira, Ana Paula Macedo, Cláudia Helena Silva Lovato, Helena de Freitas Oliveira Paranhos
Department of Dental Materials and Prosthetics, School of Dentistry of Ribeirão Preto, USP - Universidade de São Paulo, Ribeirão Preto, SP, Brazil

Correspondence: Helena de Freitas Oliveira Paranhos, Avenida do Café, S/N, 14040-904 Ribeirão Preto, SP, Brasil. Tel: +55-16-3315-4031. e-mail: helenpar@forp.usp.br

\begin{abstract}
This study evaluated color stability, surface roughness and flexural strength of acrylic resin after immersion in alkaline peroxide and alkaline hypochlorite solutions, simulating a five-year-period of use. Sixty disc-shaped $(16 \times 4 \mathrm{~mm})$ and 60 rectangular specimens $(65 \times 10 \times 3.3 \mathrm{~mm})$ were prepared from heat-polymerized acrylic resin (Lucitone 550) and assigned to 3 groups $(n=20)$ of immersion $(20 \mathrm{~min})$ : C1: distilled water; AP: warm water and one alkaline peroxide tablet; $\mathrm{SH}: 0.5 \% \mathrm{NaOCl}$ solution. Color data $(\Delta \mathrm{E})$ were determined by a colorimeter and also quantified according to the National Bureau of Standards units. A rugosimeter was used to measure roughness $(\mu \mathrm{m})$ and the flexural strength (MPa) was measured using a universal testing machine. Data were evaluated by Kruskal-Wallis followed by Dunn tests (color stability and surface roughness) and by one-way ANOVA and Bonferroni test (flexural strength). For all tests was considered $\alpha=0.05$. AP $[0.79(0.66 ; 1.42)]$ caused color alteration significantly higher than $\mathrm{C} 1[0.45$ $(0.37 ; 0.57)]$ and $\mathrm{SH}[0.34(0.25 ; 0.42)]$. The mean $\Delta \mathrm{E}$ values quantified by NBS were classified as "trace" for C1 (0.43) and SH (0.31) and "slight" for AP (0.96). SH [-0.015 $(-0.023 ; 0.003)]$ caused significantly higher $\Delta$ Ra than the $\mathrm{C} 1[0.000(-0.004 ; 0.010)]$ and AP $[0.000(-0.009 ; 0.008)]$ groups. There was no statistically significant difference among the solutions for flexural strength (C1: $84.62 \pm 16.00$, AP: $85.63 \pm 12.99$, SH: $84.22 \pm 14.72$ ). It was concluded that immersion in alkaline peroxide and $\mathrm{NaOCl}$ solutions simulating a five-year of 20 min daily soaking did not cause clinically significant adverse effects on the heat-polymerized acrylic resin.
\end{abstract}

Key Words: complete denture, denture cleansers, acrylic resins.

\section{Introduction}

The main chemical method of complete denture cleaning consists in immersing the prosthetic devices in solutions with solvent, detergent, antibacterial and antifungal actions (1). The literature has shown that sodium hypochlorite and alkaline peroxides are the two main classes of immersion denture cleansers (2). These solutions can be employed alone or associated with mechanical methods and the immersion procedures can be performed for 3 to $20 \mathrm{~min}$, or for $8 \mathrm{~h}(2,3)$.

The alkaline hypochlorites present bactericidal and fungicidal action, as well as stain removal properties and have been suggested as effective denture cleansers (4-6). Alkaline peroxides are composed by oxidant, effervescent, surface tension reducers and chelating agents commonly found in tablet or powder forms, which in contact with water become hydrogen peroxide solutions (1). Some studies indicated that the association of alkaline peroxide to brushing improved the effectiveness of hygiene $(7,8)$.

These hygiene solutions should not cause any adverse effect on the prosthetic devices' materials. Although many studies tried to show the adverse effects of denture cleansers on heat-polymerized acrylic resin, up to now most of them failed to show clinically relevant adverse effects, maybe due to the short time period in which the acrylic resin was evaluated. Color, flexural strength and surface roughness alterations of denture resins were evaluated after immersion in peroxide and $\mathrm{NaOCl}$ solutions at $0.05 \%$, $0.5 \%$ and $1 \%$, but in simulated periods of $7,90,180$ and 365 days of use $(4,9-14)$.

Paranhos et al. (15) found slight color and surface roughness alterations of acrylic resin after immersion in alkaline peroxide and $0.5 \% \mathrm{NaOCl}$ solutions, but the immersion period corresponded to the expected 1.5year time of daily overnight ( $8 \mathrm{~h}$ ) soaking. The authors highlighted the importance of evaluating the adverse effects when such solutions are employed for longer periods of immersion, since damage to denture base materials may accumulate.

Another important factor is the use of a short cycle immersion, which consists in a common hygiene routine among denture wearers, considering that an efficient immersion time is a denture cleanser request (2). Thus, the aim of this study is to simulate a 5 year period of 20min daily immersion of a heat-polymerized acrylic resin in $\mathrm{NaOCl}$ and alkaline peroxide evaluating the effect on 
color, surface roughness and flexural strength. The work hypothesis was that the immersion in denture cleansers would not influence these properties of the acrylic resin.

\section{Material and Methods}

Circular $(16 \times 4 \mathrm{~mm})$ and rectangular $(65 \times 10 \times 3.3 \mathrm{~mm})$ metallic matrices were invested in separated flasks, which were half invested with type III dental stone (Gesso-Rio, Rio Claro, SP, Brazil) and half with condensation silicone (Zetalabor, Zermack, Rovigo, Italy). The heat-polymerized acrylic resin (Lucitone 550; Dentsply, Petrópolis, RJ, Brazil) was manipulated, packed, pressed into the mold (Protecni Hydraulic Press, Araraquara, SP, Brazil) and polymerized (Thermocycler T100; Ribeirao Preto, SP, Brazil) according to the manufacturer's instructions.

The excess was trimmed and both flat sides of each specimen were polished in a horizontal lathe spindle (DP 9; Copenhagen, Denmark) with 180/320/400/600/1200-grit silicon carbide paper (Norton, Guarulhos, SP, Brazil). One of the flat faces of each specimen was polished with a polishing cloth (Fortel, São Paulo, SP, Brazil) and calcium carbonate water solution (Branco Rio, Rio Claro, SP, Brazil). Twenty circular specimens for color analyses and 40 rectangular for surface roughness and flexural strength assays were fabricated. Considering the faces (width and length) of the rectangle, four marks were made: one at half the width of the rectangular specimen and three on the length. The first mark at half the distance of its length and the other two, drawn $1 \mathrm{~mm}$ away laterally to the first (Fig. 1). The specimens were stored in distilled water at $37{ }^{\circ} \mathrm{C}$ for $50 \pm$ $2 \mathrm{~h}$ to eliminate the residual monomer.

The specimens were randomly assigned to three groups ( $n=20):$ 1) C1 (Control): $200 \mathrm{~mL}$ of distilled water; 2) AP: 200 $\mathrm{mL}$ of warm water and one effervescent alkaline peroxide tablet (Corega Tabs; GlaxoSmithKline, Middlesex, UK) and 3) $\mathrm{SH}: 200 \mathrm{~mL}$ of $0.5 \% \mathrm{NaOCl}$ solution (Injectcenter, Ribeirão Preto, SP, Brazil). A 20-minute immersion was employed for all solutions $(3,6,16)$. So, one hour represented 3 immersions of $20 \mathrm{~min}$ and each $24 \mathrm{~h}$ (one day) corresponded to 72 immersions of $20 \mathrm{~min}$ per day. Therefore, to complete a 5-year immersion simulation (1825 days), were necessary 26 days. The temperatures used were those recommended by the manufacturer for alkaline peroxide (lukewarm water $30 \pm 2^{\circ} \mathrm{C}$ ) and $23 \pm 2^{\circ} \mathrm{C}$ for the $\mathrm{NaOCl}$ and control. Solutions were changed three times a day. The specimens were evaluated at baseline and after the cleaning simulation. The number of specimens in each group was determined by previous study (power level of $80 \% ; n=19 /$ group) (15).

The color measurements were determined by a colorimeter (Color-guide, BYK-Gardner, Geretsried, Germany) with a D65 standardized lighting, $10^{\circ}$ observation angle, and a light source within the visible spectrum (400 to $700 \mathrm{~nm}$ ). The measurement geometry was $45^{\circ}$, and the area had an $11 \mathrm{~mm}$ diameter. The CIELab color system was used, and the total color alteration $(\Delta \mathrm{E})$ was calculated using the equation: $\Delta \mathrm{E}^{*}=\left[\left(\Delta \mathrm{L}^{*}\right)^{2}+\left(\Delta \mathrm{a}^{*}\right)^{2}+\left(\Delta \mathrm{b}^{*}\right)^{2}\right]^{1 / 2}$. The data were quantified according to the National Bureau of Standards (NBS) units (17) using the following formula: NBS units $=\Delta \mathrm{E} \times 0.92$; they were then classified according to: 1 ) Trace, $0.0-0.5$; 2) Slight, 0.5-1.5; 3) Noticeable, 1.5-3.0; 4) Considerable, 3.0-6.0; 5) Very, 6.0-12.0;6) Excessive, >12.0.

The surface roughness $(\triangle \mathrm{Ra})$ was evaluated with a rugosimeter (Surftest SJ-201P; Mitutoyo, Tokyo, Japan). For each specimen, three readings were performed 4.0 $\mathrm{mm}$ in length and cutoff value of $0.8 \mathrm{~mm}$ at a speed of $0.5 \mathrm{~mm} / \mathrm{s}$. The roughness of each specimen was calculated by the arithmetic mean of three measurements $(\mu \mathrm{m})$. The change in surface roughness ( $\Delta \mathrm{Ra}$ ) was obtained by the difference between the roughness after immersion and the baseline value.

The specimens were subjected to flexural strength assessment (DL 2000; EMIC, São Jose dos Pinhais, PR, Brazil) at a crosshead speed of $5 \mathrm{~mm} / \mathrm{min}$. Three-point bending tests were carried out with a distance of $50 \mathrm{~mm}$ between the two supporting points and $50 \mathrm{~kg}$ were applied onto specimen's center. Flexural strength was calculated using the formula: $S=3 \mathrm{PL} / 2 \mathrm{bd}^{2}$, where $S$ is flexural strength, $P$ is the peak load applied, $L$ is the span length, $b$ is the specimen's width and $d$ is the specimen's thickness. The calculation of the maximum flexion of the specimen was done by the tension ( $\mathrm{T}$ ) $\mathrm{x}$ deformation (d) curve. The results were expressed in $\mathrm{kgf} / \mathrm{mm}^{2}$ and converted to $\mathrm{MPa}$.

The statistical tests were performed using SPSS 17.0 program (SPSS Inc., Chicago, IL, USA). The Kolmogorov-

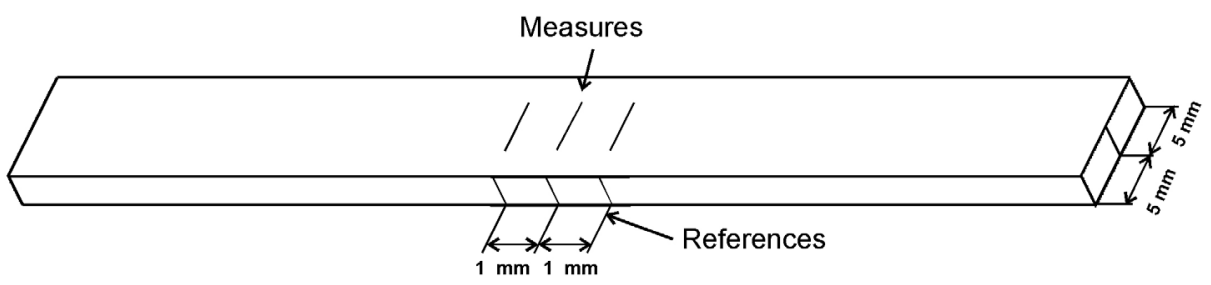

Figure 1. Schematic design of specimen measures. 
Smirnov test revealed presence of a non-normal distribution for color stability and surface roughness and normal distribution for flexural strength. Groups were compared by the Kruskal-Wallis followed by Dunn test. One-way ANOVA followed by Bonferroni test were applied for flexural strength. For all tests was considered $\alpha=0.05$.

\section{Results}

The color $\left(L^{*}, a^{*}\right.$ and $\left.b^{*}\right)$ and surface roughness measurements are shown in Table 1. Table 2 presents the final data and the results of statistical analyses.

The Kruskal-Wallis test showed a significant difference for color alteration $(p<0.01)$. Dunn test indicated significantly higher $\triangle \mathrm{E}$ for AP group than $\mathrm{SH}(\mathrm{p}<0.01)$ and $\mathrm{C} 1(p=0.04)$. The mean $\Delta E$ values were classified as "trace" (0.0-0.5) for C1 (0.43) and SH (0.31), and "slight" (0.5-1.5) for AP (0.96). For surface roughness the KruskalWallis test showed a significant difference $(p=0.02)$. SH decreased Ra values, resulting in negative $\Delta R a$, statistically different from $\mathrm{C} 1(\mathrm{p}=0.02)$. AP group showed intermediate

\begin{tabular}{|c|c|c|c|c|}
\hline \multirow{2}{*}{ Group } & \multicolumn{3}{|c|}{ Color } & \multirow{2}{*}{$\begin{array}{c}\text { Surface } \\
\text { roughness }\end{array}$} \\
\hline & $\mathrm{L}^{*}$ & $a^{*}$ & $\mathrm{~b}^{*}$ & \\
\hline \multicolumn{5}{|c|}{ Before immersion } \\
\hline C1 & $50.61(0.56)$ & $21.39(1.45)$ & $8.40(1.32)$ & $0.09(0.02)$ \\
\hline AP & $50.58(1.03)$ & $22.50(1.53)$ & $9.48(1.36)$ & $0.09(0.02)$ \\
\hline SH & $50.47(0.53)$ & $20.86(1.05)$ & $8.26(0.91)$ & $0.10(0.03)$ \\
\hline \multicolumn{5}{|c|}{ After immersion } \\
\hline $\mathrm{C} 1$ & $50.30(0.62)$ & $21.37(1.48)$ & $8.35(1.41)$ & $0.10(0.03)$ \\
\hline AP & $50.48(1.19)$ & $22.58(1.62)$ & $9.62(1.49)$ & $0.09(0.02)$ \\
\hline SH & $50.53(0.44)$ & $20.89(1.13)$ & $8.12(0.93)$ & $0.08(0.02)$ \\
\hline
\end{tabular}

C1: distilled water; AP: warm water and one alkaline peroxide tablet; $\mathrm{SH}: 0.5 \% \mathrm{NaOCl}$ solution.

Table 2. $\Delta \mathrm{E}, \Delta \mathrm{Ra}$ (median and confidence interval) and FS (Mean and standard deviations) for the evaluated groups

\begin{tabular}{ccccc}
\hline Group & $\Delta \mathrm{E}$ & NBS & $\Delta$ Ra & FS (MPa) \\
\hline C1 & $0.45(0.37 ; 0.57) \mathrm{a}$ & 0.41 & $0.000(-0.004: 0.010) \mathrm{a}$ & $84.62 \pm 16.00 \mathrm{a}$ \\
AP & $0.79(0.66 ; 1.42) \mathrm{b}$ & 0.73 & $0.000(-0.009: 0.008)$ & $85.63 \pm 12.99 \mathrm{ab}$ \\
$\mathrm{SH}$ & $0.34(0.25 ; 0.42) \mathrm{a}$ & 0.31 & $\begin{array}{c}-0.015 \\
(-0.023: 0.003) \mathrm{b}\end{array}$ & $84.22 \pm 14.72 \mathrm{a}$ \\
\hline
\end{tabular}

Different letters in columns indicate statistically significant difference $(p<0.05)$. NBS: National Bureau of Standards units. $\triangle$ Ra values. One-way ANOVA data showed no statistically significant difference among the solutions for flexural strength $(p=0.94)$.

\section{Discussion}

This study evaluated two solutions routinely indicated for complete denture hygiene and effective against denture biofilm $(4,5,7)$. Effervescent tablets have been employed in different periods of immersion $(7,8,15,18,19)$ according to manufacturer's instructions. Corega Tabs, for example, is indicated to be immersed from 5 min until $8 \mathrm{~h}$. In order to standardize the immersions, allowing comparison of the results, all solutions were immersed for 20 min $(3,6,11,16)$. The work hypothesis was rejected since the immersion solutions influenced the properties of acrylic resin.

The results showed that $0.5 \% \mathrm{NaOCl}$ did not cause alterations in color stability (Tables 1 and 2). Previous studies with disinfectant $\mathrm{NaOCl}$ solutions did not find changes in acrylic resins using 1\%,5.25\%, and $0.525 \%$ concentrations in periods of $72 \mathrm{~h}$ and 7 or 548 days of immersions $(16,17,20)$. Previous results showed that $0.5 \%$ and $1 \% \mathrm{NaOCl}$ solutions did not cause color changes of acrylic resin in simulated 20-minute immersions for 180 days (11). However, for the same period another study showed that there were "slight" color changes using 1\% $\mathrm{NaOCl}$ as overnight solutions ( $\geq 8 \mathrm{~h}$ ) (13). Porta et al. (4), in a clinical trial, found that $0.5 \% \mathrm{NaOCl}$ solution did not cause color changes simulating a 3-minute immersion for 30,60 and 90 days. Other studies that simulated 3, 6 and 12 months of use indicated that $0.5 \% \mathrm{NaOCl}$ may cause color changes, when employed in immersions of $8 \mathrm{~h}$, with a trend to increase $\Delta E$ values with time $(15,19)$. The current results showed $\Delta$ E values for $\mathrm{SH}[(0.34(0.25 ; 0.42)]$ classified as "trace" (0.0-0.5) after simulated immersions (Table 2).

Alkaline peroxide exhibited the highest color change. This product may discolor denture base resins even when following the manufacturer's instructions, showing that the type of effervescent can influence color stability $(14,15,18)$. Previous studies showed higher $\Delta \mathrm{E}$ values with Corega Tabs for $5 \mathrm{~min}$ (14) or $8 \mathrm{~h}$ (18). The agents releasing oxygen with enzymes present in peroxides may justify the oxidation and strong alkaline solution can be deleterious $(18,19)$, as shown by the obtained results. Peroxides as Efferdent (sodium perborate) and Polident (peroxide neutral enzyme) produce $\mathrm{CO}_{2}$ when dissolved in water, showing a minimum bleaching effect. Other studies did not show color changes with Corega Tabs, Efferdent Plus and Bony Plus tablets, but the analyses were visual and the simulation was just for 30 days $(21,22)$. Studies regarding denture cleansers 
have shown NBS values classified as "trace" $(0.0-0.5)(11,14)$, "slight" (0.5-1.5) (13) or "noticeable" $(1.5-3.0)(15,19)$. The current study showed that the NBS values ranged from 0.31 to 0.73 and were classified as "trace" and "slight" (Table 2). These values are considered as non-perceptible and acceptable by clinical parameters (19).

The $0.5 \% \mathrm{NaOCl}$ led to a smoother surface roughness (Tables 1 and 2), agreeing with previous studies $(15,23)$. Other studies have shown that $0.5 \%(11,13)$ and $1 \%(10)$ concentrations did not cause changes of this property. These studies employed immersion periods of 3 to $20 \mathrm{~min}$, as well as $8 \mathrm{~h}$, and 4 to 180 days simulated periods of use. Paranhos et al. (15), simulating one and a half year of use, found increase in surface roughness of an acrylic resin with a $0.5 \% \mathrm{NaOCl}$ solution. However, the current results may be related to the period of use, suggesting that increasing the exposure time to $\mathrm{NaOCl}$ solution may decrease the surface roughness. This solution acts as a solvent, changing fatty acids into fatty acid salts (soap) and glycerol (alcohol) (24). Thus, this action of sodium hypochlorite may lead to the smoothing of acrylic resin surface.

Corega Tabs tablet did not change the surface roughness (Table 2), in agreement with Peracini et al. (14) in a simulated 180 days of use period. However, these results disagree with a study that employed shorter time and period of immersion (23). Those authors discussed that manipulated sodium perborate was unable to remove the debris film on the acrylic resins and alloys, which could increase the surface roughness. These differences indicate that not only the time and immersion period should be considered, but also the type of employed cleanser. However, the data found in our study ranged from 0.00 to -0.015 and were at clinically acceptable levels $(<0.20 \mu \mathrm{m})(25)$.

It seems that the tested regimen was not able to cause significant deleterious effects on flexural strength (Table 2). These results agree with a study that used both products as overnight solutions ( $\geq 8 \mathrm{~h}$ ) (15). In $10 \mathrm{~min}$ of simulated immersions, a 1\% hypochlorite solution did not change this property (9), as well as the $0.5 \%$ and $1 \%$ denture cleanser solutions in daily immersions of $20 \mathrm{~min}$ (11). Conversely, Davi et al. (13) indicated a significantly lower flexural strength using $1 \%$ concentration as overnight solutions. Probably, these differences may be related to the used time.

Regarding peroxides, previous studies showed no change of heat and microwave-polymerized acrylic resins after use of Corega, Efferdent Plus and Bony Plus in a 30 days simulated period $(20,21)$. However, Corega Tabs and Bony Plus reduced flexural strength of a heat-polymerized acrylic resin in daily immersions for 180 days (14). Thirty immersions were performed alternating with distilled water as control group. Therefore, these differences may be related to immersion procedures and to the established control. The current study showed that all groups decreased flexural strength, not only the experimental but also the control groups (Table 2). These facts confirm that water can be deleterious to acrylic resin mechanical properties (13). However, the flexural strength results comply with the minimum value ( $65 \mathrm{MPa}$ ) set forth by the ADA specification nr. 12 (14) and may have no clinical relevance.

One limitation of the study was not performing change of the alkaline peroxide solution every $5 \mathrm{~min}$. Literature shows that alkaline peroxide effervescence is responsible for the mechanical removal of denture biofilm (1); conversely, cleansing effectiveness can also be related to the ingredients' chemical action. Chemical constituents responsible for the product disinfecting action, which remain in solution after the effervescence period, may be most responsible for the adverse effects on acrylic resin and not the effervescent action.

A point to be noted is that the present study provided evidence that $0.5 \% \mathrm{NaOCl}$ can be used as regular denture cleanser at low concentrations. It did not cause color change or alteration on flexural strength of the evaluated acrylic resin. Furthermore, the effect on surface roughness was at clinically acceptable levels. A daily safe use must be confirmed by randomized clinical trials. Future investigations on other relevant properties, as hardness, impact resistance and compressive strength are advised.

\section{Resumo}

Este estudo avaliou as alterações de cor, rugosidade de superficie e resistência à flexão de resinas acrílicas após imersão em soluções de peróxido alcalino e hipoclorito alcalino, simulando um período de cinco anos de uso. Sessenta corpos de prova circulares ( $16 \mathrm{~mm} \times 4 \mathrm{~mm}$ ) e 60 retangulares ( 65 $\mathrm{mm} \times 10 \mathrm{~mm} \times 3,3 \mathrm{~mm}$ ) de resina acrílica termicamente ativada (Lucitone 550) foram distribuídos $(n=20)$ em três grupos de imersão (20 min): $\mathrm{C1}$ : água destilada; PA: solução com água morna e uma pastilha de peróxido alcalino; HS: solução de hipoclorito de sódio a 0,5\%. A alteração de cor $(\Delta \mathrm{E})$ foi determinada por meio de colorímetro e também calculada de acordo com unidades da National Bureau of Standards (NBS). Um rugosimetro foi utilizado para mensuração da rugosidade de superfície $(\mu \mathrm{m})$ e a resistência à flexão (MPa) foi medida utilizando uma máquina universal de ensaios. Os dados foram avaliados pelo teste de Kruskal-Wallis seguido pelo teste de Dunn (estabilidade de cor e rugosidade de superfície) e análise de variância (ANOVA) a um fator seguida pelo teste de Bonferroni (resistência à flexão). Para todos os testes foi considerado $\alpha=0,05$. PA $[0,79(0,66 ; 1,42)]$ causou alterações de cor significativamente maiores que $\mathrm{C} 1[0,45(0,37 ; 0,57)] \mathrm{e}$ HS $[0,34(0,25 ; 0,42)]$. Os valores médios de $\Delta \mathrm{E}$ quantificados pela NBS foram classificados como "indiciais" para C1 $(0,43)$ e SH $(0,31)$, e "leves" para PA $(0,96)$. 0 HS $[-0,015(-0,023 ; 0,003)]$ acarretou maiores valores de $\triangle$ Ra que $\mathrm{C} 1[0,000(-0,004 ; 0,010)]$ e PA $[0.000(-0,009 ; 0,008)]$. Não houve diferença estatística significante entre as soluções para a resistência à flexão (C1: $84,62 \pm 16,00$, PA: $85,63 \pm 12,99$, HS: $84,22 \pm 14,72$ ). Concluiuse que imersões em soluções de peróxido alcalino e hipoclorito de sódio simulando imersões diárias de 20 min por um periodo de cinco anos não causaram efeitos adversos clinicamente significantes sobre a resina acrílica termicamente ativada.

\section{Acknowledgements}

The authors would like to thank to FAPESP (The São Paulo Research 
Foundation; Grant \#2011/22898-3) for the financial support.

\section{References}

1. Council on Dental Materials, Instruments, and Equipment. Denture cleansers. J Am Dent Assoc 1983;106:77-79.

2. Felton D, Cooper L, Duqum I, Minsley G, Guckes A, Haug S, et al.. Evidence-based guidelines for the care and maintenance of complete dentures: a publication of the American College of Prosthodontists. J Prosthodont 2011;20 Suppl 1:S1-S12.

3. Jagger DC, Harrison A. Denture cleansing - the best approach. Br Dent J 1995;178:413-417.

4. Porta SRS, Lucena-Ferreira SC, Da Silva WJ, Del Bel Cury AA. Evaluation of sodium hypochlorite as a denture cleanser: a clinical study. Gerodontology 2015 [Epub ahead of print. DOI: 10.1111/ger.12104].

5. Ferreira MA, Pereira-Cenci T, Rodrigues de Vasconcelos LM, RodriguesGarcia RC, Del Bel Cury AA. Efficacy of denture cleansers on denture liners contaminated with Candida species. Clin Oral Investig 2009;13:237-242.

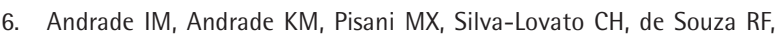
Paranhos HFO. Trial of an experimental castor oil solution for cleaning dentures. Braz Dent J 2014;25:43-47.

7. Paranhos HFO, Silva-Lovato CH, Souza RF, Cruz PC, Freitas KM, Peracini A. Effects of mechanical and chemical methods on denture biofilm accumulation. J Oral Rehabil 2007;34:606-612.

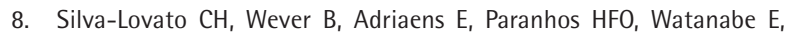
Pisani MX, et al.. Clinical and antimicrobial efficacy of NitrAdine-based disinfecting cleaning tablets in complete denture wearers. J Appl Oral Sci 2010;18:560-565.

9. Pavarina AC, Machado AL, Giampaolo ET, Vergani CE. Effects of chemical disinfectants on the transverse strength of denture base acrylic resins. J Oral Rehabil 2003;30:1085-1089.

10. Azevedo $A$, Machado $A L$, Vergani $C E$, Giampaolo ET, Pavarina $A C$, Magnani R. Effect of disinfectants on the hardness and roughness of reline acrylic resins. J Prosthodont 2006;15:235-242.

11. Paranhos HFO, Davi LR, Peracini A, Soares RB, Lovato CH, Souza RF. Comparison of physical and mechanical properties of microwavepolymerized acrylic resin after disinfection in sodium hypochlorite solutions. Braz Dent J 2009;20:331-335.

12. Paranhos HFO, Bezzon OL, Davi LR, Felipucci DN, Silva CH, Pagnano VO. Effect of cleanser solutions on the color of acrylic resins associated with titanium and nickel-chromium alloys. Braz Oral Res 2014;28:1-7.

13. Davi LR, Peracini A, Ribeiro N de Q, Soares RB, da Silva $\mathrm{CH}$, Paranhos
HFO, et al.. Effect of the physical properties of acrylic resin of overnight immersion in sodium hypochlorite solution. Gerodontology 2010;27:297-302.

14. Peracini A, Davi LR, Ribeiro N de Q, de Souza RF, da Silva $\mathrm{CH}$, Paranhos HFO. Effect of denture cleansers on physical properties of heatpolymerized acrylic resin. J Prosthodont Res 2010;54:78-83.

15. Paranhos HFO, Peracini A, Pisani MX, Oliveira V de C, de Souza RF, SilvaLovato $\mathrm{CH}$. Color stability, surface roughness and flexural strength of an acrylic resin submitted to simulated overnight immersion in denture cleansers. Braz Dent J 2013;24:152-156.

16. Pisani MX, Macedo AP, Paranhos HFO, Silva CH. Effect of experimental Ricinus communis solution for denture cleaning on the properties of acrylic resin teeth. Braz Dent J 2012;23:15-21.

17. Polyzois GL, Yannikakis SA, Zissis AJ, Demetriou PP. Color changes of denture base materials after disinfection and sterilization immersion. Int J Prosthodont 1997;10:83-89.

18. Ünlü A, Altay OT, Sahmali $S$. The role of denture cleansers on the whitening of acrylic resins. Int J Prosthodont 1996;9:266-270.

19. Hong G, Murata H, Li Y, Sadamori S, Hamada T. Influence of denture cleansers on the color stability of three types of denture base acrylic resin. J Prosthet Dent 2009;101:205-213.

20. McNeme SJ, von Gonten AS, Woolsey GD. Effects of laboratory disinfecting agents on color stability of denture acrylic resins. J Prosthet Dent 1991;66:132-136.

21. Sato $S$, Cavalcante MR, Orsi IA, Paranhos HOF, Zaniquelli O. Assessment of flexural strength and color alteration of heat-polymerized acrylic resins after simulated use of denture cleansers. Braz Dent J 2005;16:124-128.

22. Paranhos HFO, Orsi IA, Zaniquelli 0 , Zuccolotto MCC, Magalhães F. Effect of chemical denture cleansers on flexural resistance and color changes of microwave-polymerized acrylic resins. Braz J Oral Sci 2008;7:1580-1584.

23. Garcia RCR, Joane Jr AS, Rached RN, Del Bel Cury AA. Effect of denture cleansers on the surface roughness and hardness of a microwave-cured acrylic resin and dental alloys. J Prosthodont 2004;13:173-178.

24. Estrela C, Estrela CRA, Barbin EL, Spanó JCE, Marchesan MA, Pécora JD. Mechanism of action of sodium hypochlorite. Braz Dent J 2002;13:113117.

25. Zissis AJ, Polyzois GL, Yannikakis SA, Harrison A. Roughness of denture materials: a comparative study. Int J Prosthodont 2000; 13:136-40.

Received March 4, 2015 Accepted May 13, 2015 